\title{
repo encodes a glial-specific homeo domain protein required in the Drosophila nervous system
}

\author{
Wen-Cheng Xiong, ${ }^{1}$ Hideyuki Okano, ${ }^{1}$ Nipam H. Patel, ${ }^{2}$ Julie A. Blendy, ${ }^{1}$ and Craig Montell ${ }^{1,3}$ \\ ${ }^{1}$ Departments of Biological Chemistry and Neuroscience, The Johns Hopkins School of Medicine, Baltimore, Maryland \\ 21205 USA; ${ }^{2}$ Carnegie Institution of Washington, Department of Embryology, Baltimore, Maryland 21210 USA
}

\begin{abstract}
We report the identification of a Drosophila locus, reversed polarity (repo). Weak repo alleles were viable but affected glia in the optic lobe, resulting in a reversal in polarity of the electrophysiological response to light in the adult. Strong repo alleles caused defects in embryonic glia and resulted in embryonic lethality. Expression of repo appeared to be specific to glia throughout development. In the adult visual system, repo was expressed in laminal glia, medullar glia, and subretinal cells; in the embryo, repo was expressed in nearly all of the identified glia in the central and peripheral nervous systems except midline glia. The repo gene encoded a homeo domain protein suggesting that it might be a transcriptional regulator of genes required for glial development.
\end{abstract}

[Key Words: Drosophila; glia; homeo domain; development; vision; neurogenesis]

Received November 9, 1993; revised version accepted March 10, 1994.

Glial cells, the major support cells in the nervous system, have been suggested to have several functions. In vertebrates, these include roles in electrical insulation, ionic homeostasis, and provision of nutrients and factors necessary for neuronal survival and regeneration of peripheral nerves (Roitbak 1983; Vernadakis 1988; Fawcett and Keynes 1990; Barres 1991; Hatten et al. 1991; Buchanan and Benzer 1993; Marchionni et al. 1993; Masu et al. 1993). Glia also appear to play roles in neuronal development (Rakic 1971; Silver and Rutishauser 1982; Silver et al. 1982; Doucette 1990; Stitt et al. 1991; Eccleston 1992).

The morphology of many glial cell types has been described in a variety of insects; however, the functions of the glia are not understood as well as in vertebrates (for review, see Carlson and Saint Marie 1990). Nevertheless, it seems likely that invertebrate glia perform many of the same functions in the nervous system, such as electrical insulation and ionic homeostasis, as in vertebrates (Carlson and Saint Marie 1990). Several studies indicate that glia play important roles in axonal pathfinding in the insect nervous system (Bastiani and Goodman 1986; Fredieu and Mahowald 1989; Jacobs and Goodman 1989). A recent study has shown that a factor secreted by glia is capable of negatively regulating the proliferation of neuronal precursor cells in Drosophila (Ebens et al. 1993). In addition, analyses of the dropdead locus has led to the

${ }^{3}$ Corresponding author. suggestion that disruption of glial function contributes to neural degeneration (Buchanan and Benzer 1993).

Glial development has been characterized in a number of vertebrate systems (for review, see Raff 1989; Cameron and Rakic 1991; Goldman and Vaysse 1991; Le Douarin et al. 1991; Jessen and Mirsky 1992). In Drosophila, although many glial cell types have been described (Fredieu and Mahowald 1989; Klämbt and Goodman 1991; Udolph et al. 1993), the origins of the glia are known in only a few cases (Crews et al. 1988; Doe et al. 1988; Jacobs et al. 1989; Klämbt et al. 1991; Winberg et al. 1992; Giangrande et al. 1993; Udolph et al. 1993).

A number of Drosophila loci have been identified that are expressed in embryonic glia, in addition to other cell types. These include a group of genes, such as the spitz group (single-minded, slit, Star, spitz, rhomboid, and pointed), breathless and orthodenticle (otd), that are expressed in a group of glia, called midline glia, which lie adjacent to the commissures (axon tracts that link the two longitudinal connectives; Crews et al. 1988; Thomas et al. 1988; Bier et al. 1990; Finkelstein et al. 1990; Nambu et al. 1990; Rothberg et al. 1990; Klämbt et al. 1991, 1992; Rutledge et al. 1992; Klämbt 1993). The phenotypes of these mutants indicate that the midline glia play an important role in the separation of the two commissures. Other loci, such as prospero (pros), otd, pointed and fushi tarazu ( ftz) are expressed in longitudinal glia as well as in neurons and other cell types (Doe et al. 1988, 1991; Finkelstein et al. 1990; Vaessin et al. 1991; Klämbt 1993). The longitudinal axon tracts are ei- 
ther missing or defective in these mutants, but it is not known whether the phenotypes are attributable primarily to abnormalities in the longitudinal glia or in the neurons that form these pathways. Drosophila genes have also been identified that are expressed in glia in the visual system. These include cut, a locus regulating sensory organ identity, tramtrack, a gene encoding a transcription factor required for eye development and embryogenesis, and optomotor-blind, a putative transcription factor required in the optic lobe (Blochlinger et al. 1993; Poeck et al. 1993; Xiong and Montell 1993). Each of these genes is expressed in either photoreceptor cells or cone cells in addition to glia. Recently, the Drosophila anachronism locus has been identified and shown to encode a glycoprotein that is secreted by glia and inhibits neuroblast proliferation (Ebens et al. 1993).

We report the isolation of a mutation in a locus, reversed polarity (repo) that encoded a glial-specific homeo domain protein. This locus appeared to be required for proper differentiation of glia in the visual system and in the embryonic nervous system. A weak mutation in repo resulted in a dramatic electrophysiological phenotype attributable to defects in glia in the adult visual system. Strong repo alleles resulted in embryonic lethality.

\section{Results}

repo mutant identified on the basis of a reversedpolarity ERG phenotype

The repo locus was identified in a screen for recessive autosomal P-element-induced mutations affecting the physiology of the adult visual system by performing electroretinogram (ERG) recordings, an extracellularly recorded, light-evoked mass response of the eye. The wildtype ERG consists of a corneal-negative sustained component and a transient component, the off-transient, which is coincident with the cessation of the light stimulus (Fig. 1A). The sustained component of the ERG corresponds mainly to summed responses of all the cells in the retina and the off-transient originates from the neurons in the lamina (L-neurons; Buchner 1991; Minke and Selinger 1992). The repo ${ }^{1}$ mutant was characterized by an ERG of reversed polarity (Fig. 1B). No other lines, among 7000 tested, exhibited this phenotype. The repo ${ }^{1}$ allele was a weak allele (hypomorphic) and strong alleles $\left(\right.$ repo ${ }^{3}$ and repo ${ }^{4}$, identified among a collection of P-element-induced lethal lines (Karpen and Spradling 1992), caused lethality during embryogenesis (Table 1).

Each of the four repo alleles $\left(\right.$ repo $^{1}$, repo $^{2}$, repo ${ }^{3}$, and repo ${ }^{4}$ ) contained a single P-element that mapped to 90F1-2 by in situ hybridization to polytene chromosomes using a P-element specific probe (data not shown). The repo ERG and embyronic lethal phenotypes were caused by the $P$ element because, upon excision of the $P$ element from the repo ${ }^{1}$ or repo ${ }^{4}$ alleles, a high percentage of the lines reverted to wild-type (see Materials and methods, Fly stocks and genetics). One of the lines, repo ${ }^{4 e 19}$, was found to be a null allele (see below).

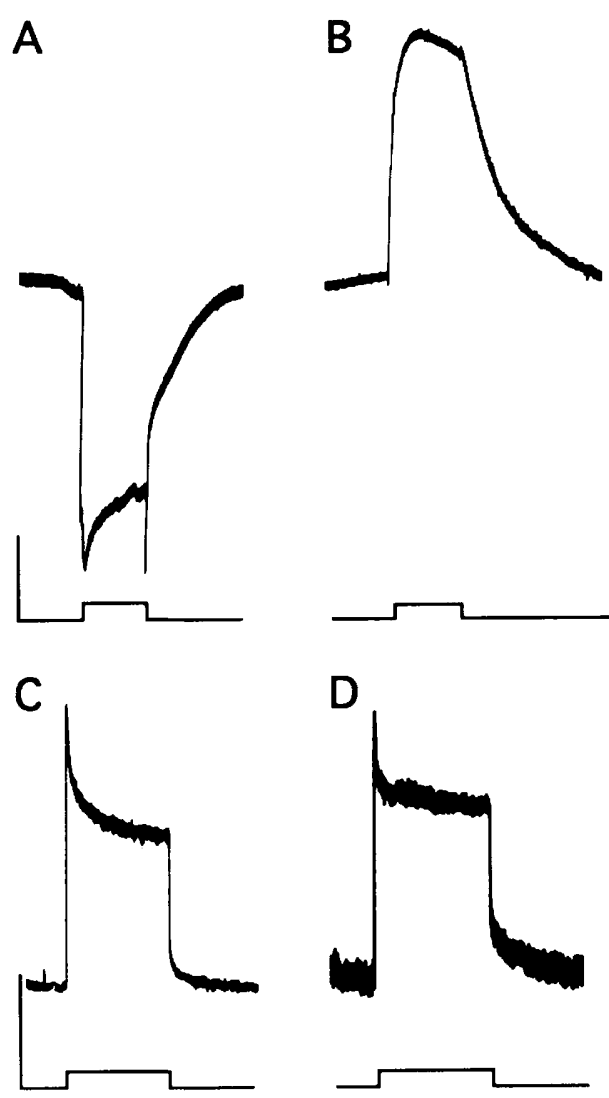

Figure 1. ERG and intracellular recordings of wild type and repo ${ }^{1}$. (A) Wild-type ERG (Canton-S); $(B)$ repo ${ }^{1}$ ERG; $_{(C)}$ wildtype intracellular recording; $(D)$ repo $^{1}$ intracellular recording. The on-transients were typically not detected in the ERGs because of limitations in the sampling rate of the analog-digital converter. An event marker below the recordings indicates the initiation and cessation of the light stimulus. The duration of the light stimulus was $5 \mathrm{sec}$ for the ERGs and $10 \mathrm{sec}$ for the intracellular recording. The vertical lines adjacent to the left end of the event markers in $A$ and $C$ are $10 \mathrm{mV}$ scales. The recordings shown were representative of flies $<7$ days old.

The unique repo ERG phenotype was not attributable to a defect in photoreceptor cells

The phenotypes of all previously characterized Drosophila mutants that affect the sustained component of the ERG have been shown to be attributable to defects in

Table 1. repo Alleles

\begin{tabular}{|c|c|}
\hline Genotype & Phenotype \\
\hline 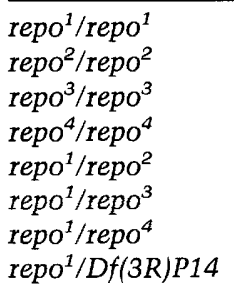 & $\begin{array}{l}\text { viable (repo ERG) } \\
\text { lethal } \\
\text { lethal } \\
\text { lethal } \\
\text { semilethal (repo ERG) } \\
\text { lethal } \\
\text { lethal } \\
\text { lethal }\end{array}$ \\
\hline
\end{tabular}


photoreceptor cells (for review, see Montell 1989; Smith et al. 1991; Minke and Selinger 1992). To determine whether the repo phenotype was attributable to a disruption of a photoreceptor cell function, intracellular recordings on photoreceptor cells were performed. The results demonstrated that the repo ERG was attributable to a defect in a cell type other than photoreceptor cells, as the polarity of the receptor potential in wild-type and repo photoreceptor cells was the same (Fig. 1C-D).

repo appeared to be expressed specifically in glia throughout development

The presumptive spatial localization of repo at several stages of development was determined by examining expression of the lac $Z$ reporter gene present within the $\mathbf{P}$ element in repo ${ }^{2}$, repo $^{3}$, and repo ${ }^{4}$ heterozygous flies /the $P$ element that induced the repo ${ }^{1}$ mutation did not contain a $l a c Z$ reporter gene). The reporter gene appeared to reflect the expression of the repo gene accurately because the spatial distributions of the $\beta$-galactosidase and repo RNA were similar in embryos (see below).

The pattern of repo lac $Z$ expression was similar to the spatial distribution of a known glial marker. In the adult stage, repo $\beta$-galactosidase staining was detected in the laminal and medullar regions of the optic lobes. The stained cells within the lamina were found to be associated with the proximal as well as distal surface of the laminal neuropil (Fig. 2A). The lacZ-positive cells in the medulla were distributed around the periphery (Fig. 2A). The nuclei of the lacZ-positive cells had a flattened appearance, a morphology distinct from the more rounded nuclei typical of neurons in the optic lobe. The repo lacZ distribution resembled the pattern of the glial marker, 3-109 (Figs. 2A and 3A; Klämbt and Goodman 1991; Winberg et al. 1992). Judging from the location of the lacZ-positive cells, nuclear morphology, and comparison with the 3-109 expression pattern, it appeared that these cells were glia. The lamina glia appeared to correspond to the marginal glia, epithelial glia, satellite glia, and subretinal cells (Trujillo-Cenoz and Mekamed 1973; Shaw 1977; Saint Marie and Carlson 1983; Cagan and Ready 1989). No lacZ expression was detected in photoreceptor cells or any cells in the retina.

We found that repo lacZ reporter gene expression was also restricted to glial cells in the third-instar larvae based on the characteristic position, morphology of the lacZ-positive cells, and comparison with the 3-109 expression pattern (Figs. 2B and 3C). $\beta$-Galactosidase staining was detected in a group of glial cells, subretinal cells, which reside in the eye disc at this stage of development (Fig. 2B; Cagan and Ready 1989). In the larval brain, the highest level of lacZ expression was in the region that develops into the optic lobes (data not shown).

In the embryo, the repo lac $Z$ reporter was expressed in many nuclei in the embryonic central nervous (CNS) and peripheral nervous system (PNS; Fig. 4A). A similar expression pattern was detected by localizing repo RNA by the in situ hybridization technique (Fig. 4B). Many of the
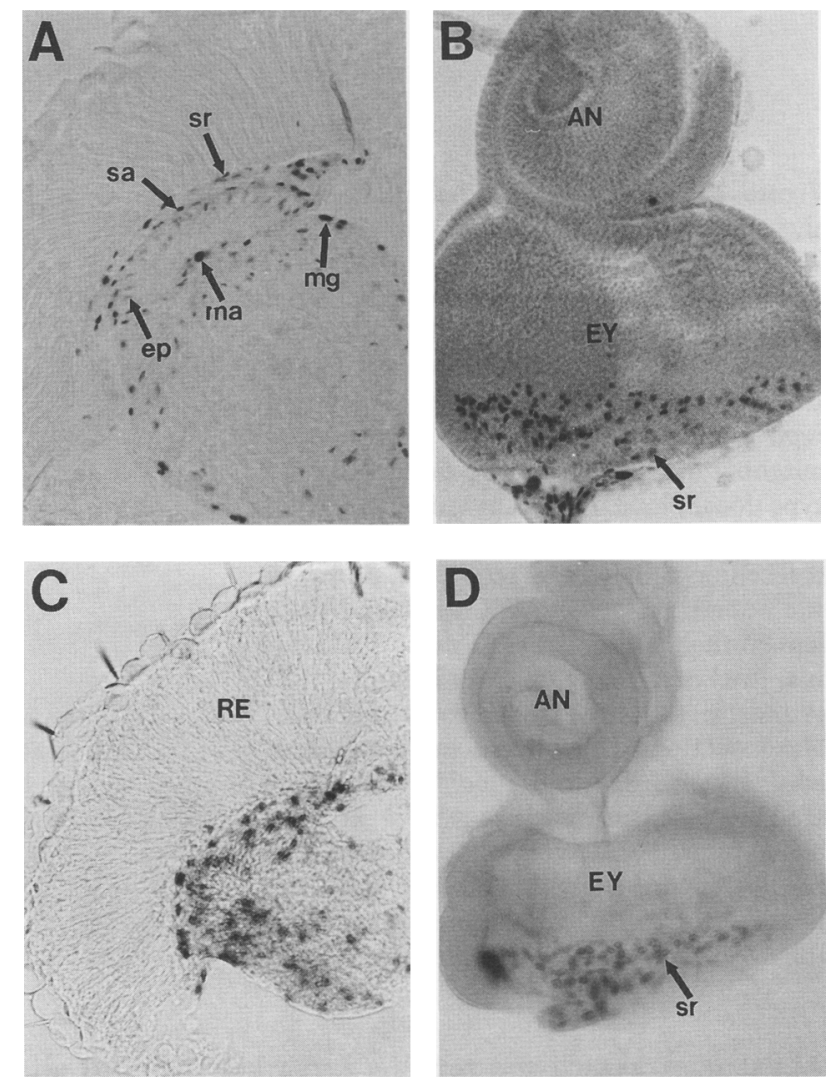

Figure 2. Expression of repo lacZ in the wild-type and repo visual system. (A) Wild-type $\left(\right.$ repo $^{3}$ heterozygote $)$ adult head section; $(B)$ wild-type $\left(\right.$ repo $^{3}$ heterozygote) larval eye-antennal disc; (C) repo adult head section $\left(\right.$ repo $^{1} /$ repo $\left.^{2}\right) ;(D)$ repo $\left(\right.$ repo $^{1} /$ repo $\left.^{2}\right)$ larval eye-antennal disc. Wild-type tissue $(A, B)$ was stained with an anti- $\beta$-galactosidase mouse monoclonal antibody and repo tissue $(C, D)$ was stained for $l a c Z$ activity. (AN) Antennal disc $_{j}$ (ep) epithelial glia (EY) eye disc; (ma) marginal glia; $(\mathrm{mg}$ ) medulla glia; (RE) retina; (sa) satellite glia (sr) subretinal cells. repo ${ }^{2}$ heterozygotes had an expression pattern similar to repo ${ }^{3}$ heterozygotes (data not shown). The adult head sections were prepared from flies $<2$ days old.

cells in the CNS were located around the longitudinal connectives and others prefigured the location where the intersegmental nerve root leaves the longitudinal connectives (Fig. 4C). In the PNS, some lacZ-positive cells were situated just outside of the CNS at a choice point of the two major nerve roots, the intersegmental and the segmental nerves (exit glia); others surrounded the peripheral nerves (peripheral glia; Fig. 4D). The lacZ-positive cells did not express a neuronal marker, ELAV (Fig. 5; Bier et al. 1988; Robinow and White 1988). Therefore, the cells expressing $\beta$-galactosidase appeared to be nonneuronal. Based on the positions and non-neuronal identities of these cells, we concluded that the repo laczpositive cells were glia. Many of these corresponded to previously identified glia: longitudinal, nerve root, exit, and peripheral (Jacobs et al. 1989; Klämbt and Goodman 1991). In addition to these axon-associated glia, other 
Figure 3. Expression of glial markers in the visual system. X-gal staining $|A-D|$. Anti-OTD antibody staining $(E-F)$. (A) Wild-type adult (3-109 heterozygote) head section; $(B)$ repo adult $\left(3-109\right.$, repo ${ }^{1 e 44}$ / repo $\left.^{1 e^{44}}\right)$ head section; $(C)$ wild-type (3-109 heterozygote) larval eye-antennal disc; $(D)$ repo $\left(3-109\right.$; repo $^{1 e 44} /$ repo $\left.^{1 e 44}\right)$ larval eyeantennal disc; $; E \mid$ larval eye disc from wild type (focal plane on the subretinal cells); $(F)$ repo ${ }^{1}$ larval eye disc (focal plane on the photoreceptor cells; there was no staining in the subretinal cells). (AN) Antennal disc; (ep) epithelial glia; (EY) eye disc; (LA) lamina; (ma) marginal glia; (ME) medulla; (RE) retina; (sa) satellite glia; (sr) subretinal cells. Head sections $(A, B)$ were prepared from adult flies $<2$ days old. repo ${ }^{1 e 44}$ was generated by mobilization of the repo ${ }^{1} \mathrm{P}$ element and exhibited an ERG phenotype similar to repo ${ }^{1}$ (data not shown). This line was used because it was $r y^{-}$and facilitated crossing the 3-109 $\mathrm{ry}^{+}$line into a repo background.
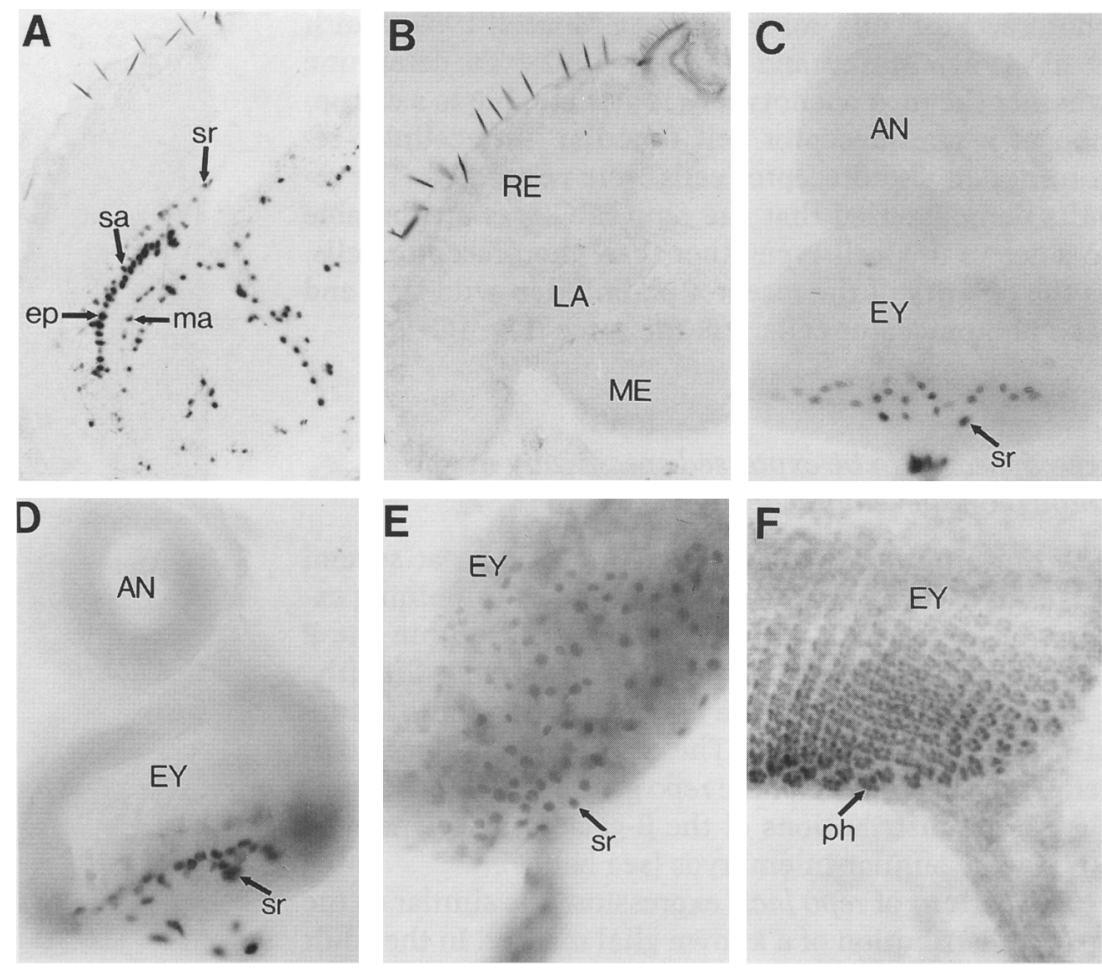

glia that expressed the repo lacZ marker included glia adjacent to cell bodies in the ventral nerve cord as well as that associated with the surface of the ventral nerve cord (data not shown). The midline glia did not express the repo lacZ.

\section{Expression of glial markers altered in repo}

To examine whether there were defects in glia in the repo visual system, we stained repo adults with a P-element enhancer trap insertion line, 3-109, which directs glial-specific lac $Z$ expression in subretinal cells, satellite glia, epithelial glia, marginal glia, and medullar glia (Winberg et al. 1992; Fig. 3A). When the 3-109 enhancer trap element was crossed into a viable repo allele, repo $^{1 e 44}$, there were few lacZ-positive cells (Fig. 3B). Furthermore, the level of $\beta$-galactosidase staining in the few cells that were still lacZ positive was low (Fig. 3B). We also stained wild-type and repo ${ }^{1}$ adult heads with an antibody to OTD that stained many glia in the wild-type visual system (data not shown). In the repo visual system, the glia did not express OTD (data not shown).
Figure 4. Expression of repo in embryos. $(A)$ Whole-mount heterozygous repo ${ }^{3}$ embryo stained with an anti- $\beta$-galactosidase mouse monoclonal antibody; $(B \mid$ repo RNA expression detected by in situ hybridization to a wild-type whole-mount embryo; $(C)$ higher magnification of the longitudinal glia $(\mathrm{lg})$ and nerve root glia (ng) stained with anti- $\beta$-galactosidase. $(D)$ Higher magnification of the exit glia (eg) and peripheral glia (pg) stained with anti- $\beta$-galactosidase.
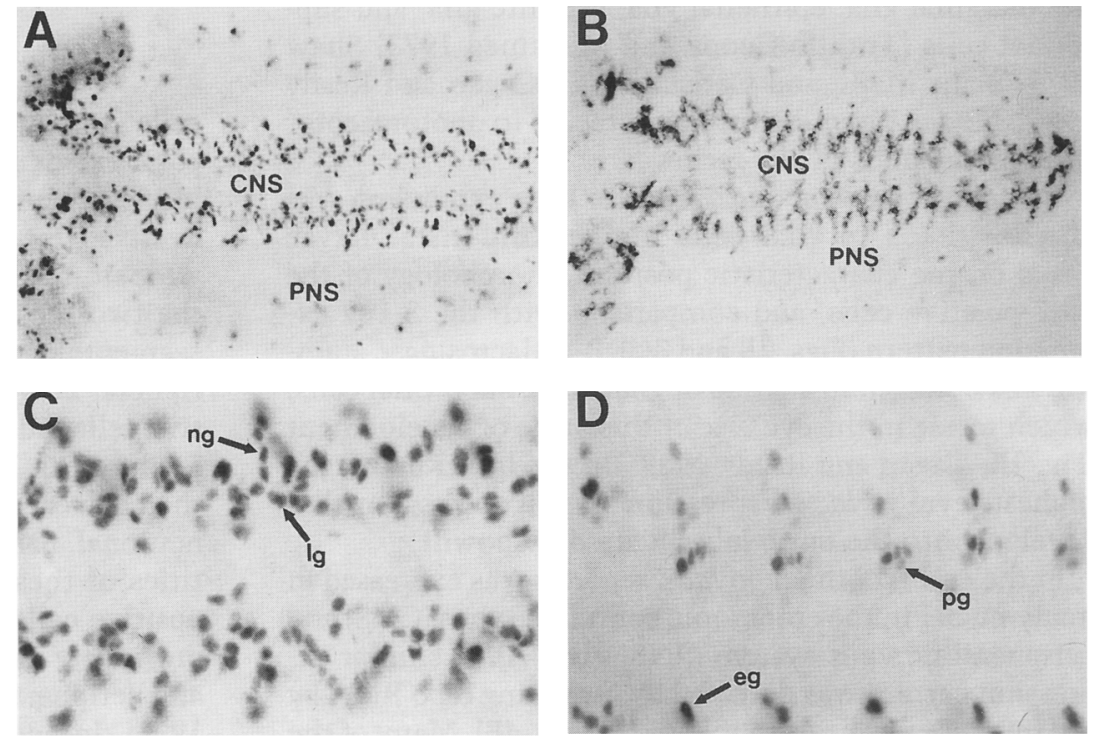

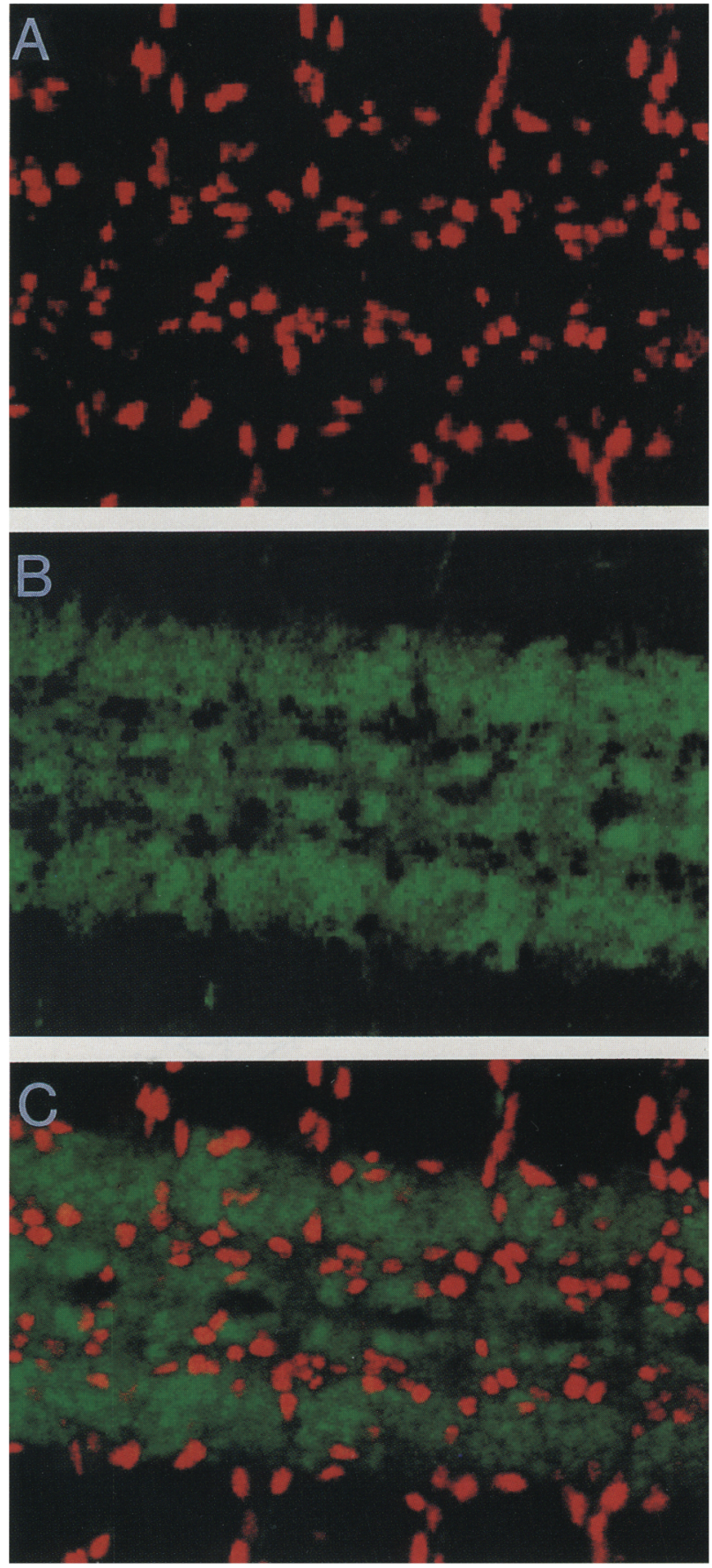

Figure 5. repo lacZ-positive cells do not express a neural marker. Double labeling of the repo heterozygous embryonic nervous system with anti-ELAV (mouse monoclonal) and anti$\beta$-galactosidase (rabbit antiserum). The secondary antibodies were FITC-labeled goat anti-mouse and RITC-labeled goat antirabbit antibodies. Shown are the fluorescent images obtained by confocal microscopy. (A) repo lacZ expression (red); (B) ELAV (green); (C) repo lacZ (red), ELAV (green).

The observation that expression of both 3-109 and OTD was absent in most of the repo glia suggested that either there was a defect in glial cell differentiation or that cell death had occurred. To distinquish between these possibilities, we stained repo adults with one of the lethal lines, repo ${ }^{2}$, which produced a few viable adults in a heteroallelic combination with repo ${ }^{1}\left(\right.$ repo $^{1}$ is not a lacZ line). The few adults that emerged displayed an ERG phenotype similar to repo ${ }^{1}$ (data not shown). The number of lacZ-positive cells in the repo ${ }^{1} /$ repo $^{2}$ visual system was similar to repo $\mathrm{o}^{2} /+$, although the spatial distribution of some of the cells was abnormal (Fig. 2C). This result suggested that the lack of 3-109 and OTD staining was not attributable to absence of the lacZ-positive cells in young repo adults $(<2$ days old). In addition, the lacZ-positive cells in repo adults did not appear to be transformed into neurons because they did not express the ELAV neuronal marker (data not shown). However, in older repo adults (>7 days old), many of the lamina glia were absent (data not shown). Further experiments will be required to determine whether the dissappearance of these cells in older flies was attributable to necrosis or apoptosis.

Developing eye discs and optic lobes from repo ${ }^{1}$-thirdinstar larvae were also examined with the glial markers. The number and pattern of repo lacZ-positive cells in wild-type and repo eye discs was similar (Fig. 2B,D). Expression of 3-109 is detected in wild-type subretinal cells, and satellite, marginal, and epithelial glia early in glial development well before they acquire a fully differentiated phenotype (Winberg et al. 1992). Despite the pronounced change in 3-109 lacZ expression in lamina glia and subretinal cells in repo adults, similar numbers of cells expressed the 3-109 marker in wild-type and repo eye discs (Fig. 3C,D). OTD was expressed in the subretinal cells and all the photoreceptor cells in wild-type eye discs (Fig. 3E; Wieschaus et al. 1992). In repo ${ }^{1}$ eye discs, OTD was expressed only in the photoreceptor cells (Fig. 3 F) and not in the subretinal cells.

To determine whether there were defects in glia in the repo embryonic nervous system, we stained the embryos with an antibody to the repo lac $Z$ in wild-type and strong repo alleles. We found that a similar number of cells expressed lacZ in wild-type and mutant embryos (Fig. $6 \mathrm{~A}, \mathrm{~B} \mid$. We also stained wild-type and repo embryos with another glia marker, OTD. In wild type, OTD is expressed in the midline cells (including midline neurons and glia), longitudinal glia, exit glia, and peripheral glia (Finkelstein et al. 1990; Fig. 6C,E). In repo embryos, only the midline cells, which do not express repo, expressed OTD (Fig. 6D). No expression of OTD was detected in the longitudinal glia, exit glia, or peripheral glia (Fig. $6 \mathrm{D}, \mathrm{F})$.

\section{Examination of CNS and PNS axon tracts in repo embryos}

The repo embryonic nervous system was examined for morphological defects because repo was expressed specifically in the nervous system. The longitudinal axon tracts in wild-type embryos, stained with BP102, appear as two continuous parrallel bundles extending the length of the embryo. Between stages 13 and 15, there is con- 

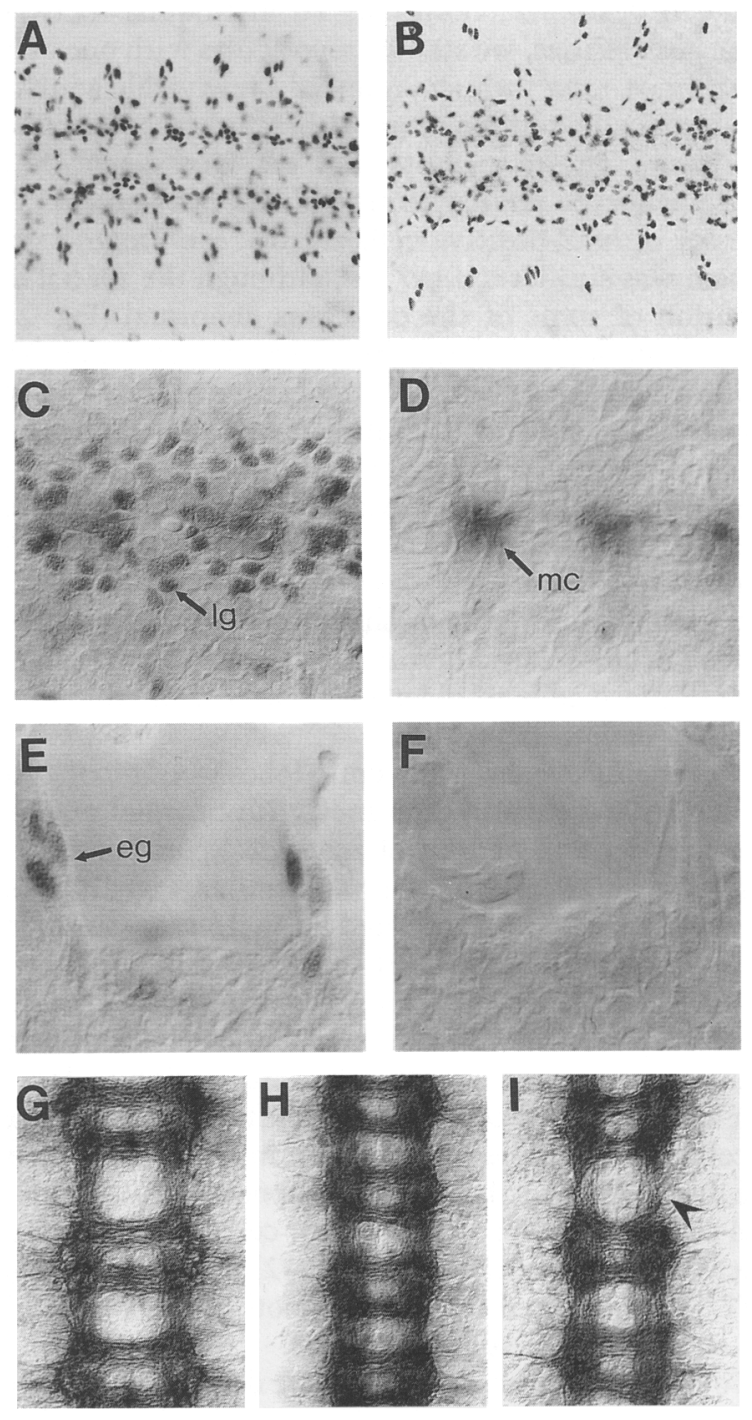

Figure 6. Expression of glial markers in embryos and the repo embryonic CNS axon pattern. Staining performed with wholemount embryos and HRP-conjugated secondary antibodies. $(A)$ repo ${ }^{4}$ heterozygous embryo stained with a mouse anti- $\beta$-galactosidase antibody; $(B)$ repo $0^{4 e 25}$ homozygous embryo stained with a mouse anti- $\beta$-galactosidase antibody [similar staining was obtained with the null allele $\operatorname{repo}^{4 e 19}$ (data not shown)]; $(C)$ longitudinal glia $(\mathrm{lg})$ and midline cells $(\mathrm{mc})$ in wild-type embryo stained with anti-OTD; $(D)$ repo $^{3}$ embryo stained with antiOTD did not show longitudinal glia expression; $|E|$ wild-type embryo stained with anti-OTD showed exit glia (eg) expression; (F) repo ${ }^{3}$ embryo stained with anti-OTD did not show expression in exit glia; $(G)$ wild-type stage 13 and stage $15 ;(H)$ CNS axons stained with BP102; $(I) \mathrm{repo}^{3} / \mathrm{Df}(3 \mathrm{R}) \mathrm{P} 14$ axons stained with BP102.

densation of the CNS resulting in thickening of the longitudinal tracts (Fig. 6G, H). This condensation appeared normal in the strongest repo alleles, repo and repo ${ }^{4}$. In $30-50 \%$ of $r e p o^{3} / D f(3 R) P 14$ and repo $/ D f(3 R) P 14$ stage 15 embryos there was thinning in the longitudinal tracts in some segments apparently due to poor condensation
(Fig. 6I). Thus, it was unclear whether the strongest repo alleles, repo ${ }^{3}$ and repo ${ }^{4}$, represented the null phenotype. Another repro allele, repo ${ }^{4 e 19}$, obtained by mobilization of the $\mathrm{P}$ element from the repro ${ }^{4}$ allele, appeared to be a null allele because there was an imprecise excision of the $\mathrm{P}$ element resulting in deletion of part of the repo protein-coding region (see below). repo ${ }^{4 e 19}$ embryos exhibited a phenotype similar to repo ${ }^{3}$ and repo ${ }^{4}$ (data not shown). These results suggested that there may be another gene within the deficiency whose absence contributed to the improper condensation of the longitudinal axon tracts. No defects in PNS axons were detected in repo embryos stained with $22 \mathrm{Cl0}$ (data not shown).

\section{Identification of repo $m R N A$}

The repo genomic region was cloned by virtue of P-element insertions (see Materials and methods). The positions and orientations of the P-element insertions in the four repo alleles are shown in Figure 7. In addition, the approximate segment of repo genomic DNA deleted in repo $^{4 \mathrm{e} 19}$, which removed the initiating ATG codon /see Materials and methods), is indicated.

Several lines of evidence indicated that repo encoded a 3.5-kb mRNA. First, a $3.5-\mathrm{kb}$ mRNA was identified on RNA blots using probes flanking the P-element insertion sites. Second, each of the P elements in the four repo

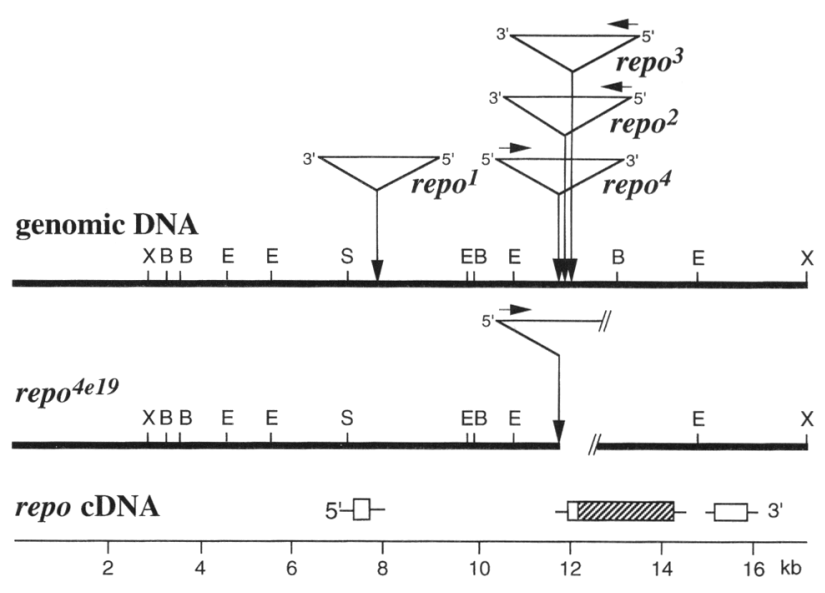

Figure 7. Physical map of repo locus. A $17-\mathrm{kb}$ portion of the repo genomic region is represented by the bottom horizontal line demarcated in kilobase pairs and by the restriction sites $B a m H I(B), E c o R I$ (E), SalI (S), XbaI (X). The insertion sites of the mutator $\mathrm{P}$ elements from repo ${ }^{1}$, repo $^{2}$, repo $^{3}$ and repo ${ }^{4}$ are indicated by the vertical arrows above the genomic DNA. The orientations of the $l a c Z$ genes in the $\mathrm{P}$ elements are indicated by the horizontal arrows. The middle horizontal line represents repo ${ }^{4 e 19}$ genomic DNA. The break in this line indicates the region deleted in repo ${ }^{4 e 19}$ genomic DNA. The approximate transcribed region, determined by probing Southern blots containing repo cloned genomic DNA with ${ }^{32} \mathrm{P}$-labeled pcrepo-2.6 and pcrepo- 2.2 cDNAs, is indicated by the boxes. The horizontal lines extending from the boxes indicate the extent of uncertainty in the mapping. The translated region is indicated by the portion of the box marked with a hatched box. The $5^{\prime}-$ and $3^{\prime}$-untranslated regions are represented by the open boxes. 
alleles interrupted the transcription unit encoding the $3.5-\mathrm{kb}$ mRNA. The repo ${ }^{1}$, repo $^{2}$, and repo ${ }^{4} \mathrm{P}$ elements inserted into introns, and the repo ${ }^{3} \mathrm{P}$ element inserted into the $5^{\prime}$-untranslated region (Fig. 7). Third, the concentration of the $3.5-\mathrm{kb}$ mRNA was reduced in the repo ${ }^{1}$ hypomorphic allele (Fig. 8). A heterogeneous population of higher molecular weight RNAs was also detected in repo ${ }^{1}$ RNA from adults. The heterogeneous RNAs were not detected upon reprobing repo ${ }^{1}$ RNA with another Drosophila gene expressed in the adult (Fig. 8). Fourth, the spatial expression pattern of the $3.5-\mathrm{kb}$ mRNA was similar to the lac $Z$ pattern described above (see below).

Expression of repo RNA during Drosophila development was investigated by probing a developmental RNA blot with the repo cDNA (data not shown). The highest levels of expression were in embryos and adult heads.

\section{repo encodes a homeo domain protein}

The nearly full-length sequence of the repo mRNA was obtained from two overlapping cDNAs (Fig. 9A). A single long open reading frame, encoding a putative 612-aminoacid protein, with a predicted molecular mass of $66 \mathrm{kD}$ was identified. Comparison of the deduced amino acid sequence with the sequence data banks revealed the presence of a homeo domain, a 60-amino-acid motif conserved among many transcription factors important in the development of a wide variety of vertebrate and invertebrate organisms (Scott et al. 1989).

Homeo domains have been divided into a number of classes based on amino acid sequence (Scott et al. 1989). The REPO homeo domain was most similar to the paired-(PRD)-like group, which includes paired (prd), aristaless $(a 1)$, gooseberry $(g s b)$, gooseberry-neuro $(g s b n)$,

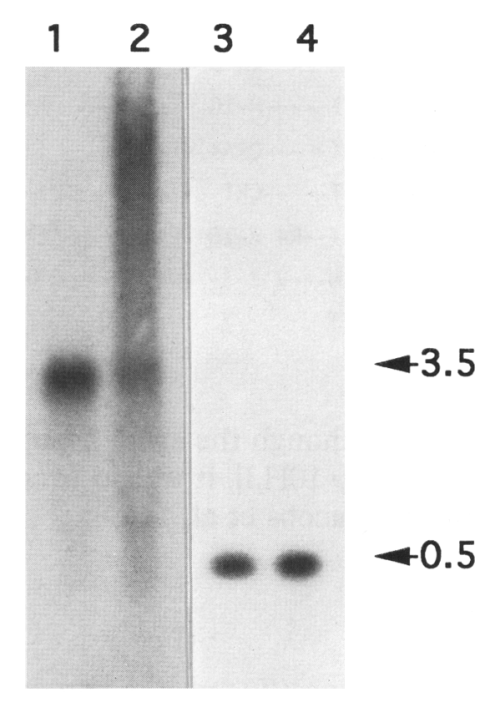

Figure 8. RNA blot analysis. repo RNA-expressed in wild-type and repo ${ }^{1}$ adults. (Lanes 1,3 ) Wild-type RNA; (lanes 2,4) repo ${ }^{1}$ RNA. Lanes 1 and 2 were probed with a repo 0.6-kb PstI-cDNA fragment (nucleotides 1365-1985); lanes 3 and 4 were probed with a ribosomal protein cDNA, rp49. The sizes of the repo and rp49 RNAs are indicated at right in $\mathrm{kb}$. pax-3, pax-6, and pax-7 (Bopp et al 1986; Frigerio et al. 1986; Goulding et al. 1991; Jostes et al. 1991; Walther and Gruss 1991; Schneitz et al. 1993). Within this class, the REPO homeo domain was related most closely $(\sim 70 \%)$ to murine PAX-3, Caenorhabditis elegans UNC-4 and Drosophila ARISTALESS (AL) (Fig. 9B; Goulding et al. 1991; Miller et al. 1992; Schneitz et al. 1993). Among the 16 PRD-specific amino acids, 14 were either identical or conserved (Bopp et al. 1986). One of the two nonconservative changes among the PRD-specific amino acids was the serine to glutamine change at position 50 . This residue has been shown previously to be a major determinant of homeo domain DNA-binding specificity in PRD and BICOID $(B C D$; Hanes and Brent 1989; Treisman et al. 1989). The AL and UNC-4 homeo domains have the same amino acid at residue 50 as REPO (Fig. 9B; Miller et al. 1992; Schneitz et al. 1993). A subset of PRD-like homeo domain proteins contains an additional homology of 18 amino acids extending from the amino terminus of the homeo domain (Bopp et al. 1986). Certain PRD-like homeo domain proteins also contain two additional regions of homology: an $\sim 130$ amino-acid paired box and and a conserved octapeptide (Bopp et al. 1986). The repo sequence did not contain significant homology to other PRD-like homeo domain proteins outside of the homeo box.

The predicted REPO protein also contains multiple sequences consisting of single amino acid repeats. The longest and most frequent was six stretches of four to nine glutamines, referred to as opa repeats, found frequently in other developmentally important Drosophila proteins (Wharton et al. 1985; Finkelstein et al. 1990; Nambu et al. 1990).

\section{Examination of glial cell lineage in the embryo using repo as a marker}

Many glial cell types have been described in Drosophila embryos (Fredieu and Mahowald 1989; Klämbt and Goodman 1991; Udolph et al. 1993). However, the origins of the glia in the embryo are known in only a few cases. The midline glial cells are the progeny of mesectodermal precursors (Crews et al. 1988; Klämbt et al. 1991). The longitudinal glial cells originate from lateral glioblasts (Doe et al. 1988; Jacobs et al. 1989). Both the midline and longitudinal glia derive from progenitors restricted to glial cell fate. Recently, It has been found that the so-called A and B glial cells derive from the same precursor as the aCC and pCC neurons (Udolph et al. 1993).

In situ hybridization of wild-type embryos with repo DNA confirmed that repo was expressed in glia in a bilateraly symmetrical pattern consistent with the $l a c Z$ expression pattern described above. Expression of repo first appeared during germ-band extension in stage $9 \mathrm{em}$ bryos (Fig. 10A,B). Expression was restricted primarily to the glioblasts (GBs) that were identified based on their location (Jacobs et al. 1989). The GBs were located in the lateral-most row of neuroblasts (NBs) and at the anterior 
Figure 9. (A) Nucleotide sequence of the repo cDNAs and deduced amino acid sequence of the putativerepoprotein. The predicted amino acid sequence is shown under the nucleotide sequence. The homeo domain sequence is underlined. Three mRNA instability motifs ATTTA; $^{-}$ Shaw and Kamen 1986) and two consensus 3 '-end processing signals (AATAAA) were found in the $3^{\prime}$-untranslated region. The $3.2-\mathrm{kb}$ sequence was obtained from analyses of pcrepo-2.6 (nucleotides 1-2552) and pcrepo-2.2 (nucleotides 985-3210). (B) Sequence homology to members of the PRDlike homeo domain proteins. A comparision between repo and several other homeo box sequences is shown (Bopp et al. 1986; Frigerio et al. 1986; Finkelstein et al. 1990; Goulding et al. 1991; Krauss et al. 1991; Ton et al. 1991; Miller et al. 1992; Schneitz et al. 1993). Amino acid identities with REPO are indicated by a dash, and the number of amino acid identities with REPO are shown to the right of the lineup. The PRD-specific amino acids are shown at the bottom (Walther and Gruss 1991). The two PRD-specific amino acids not conserved in the REPO homeo domain are underlined.
A

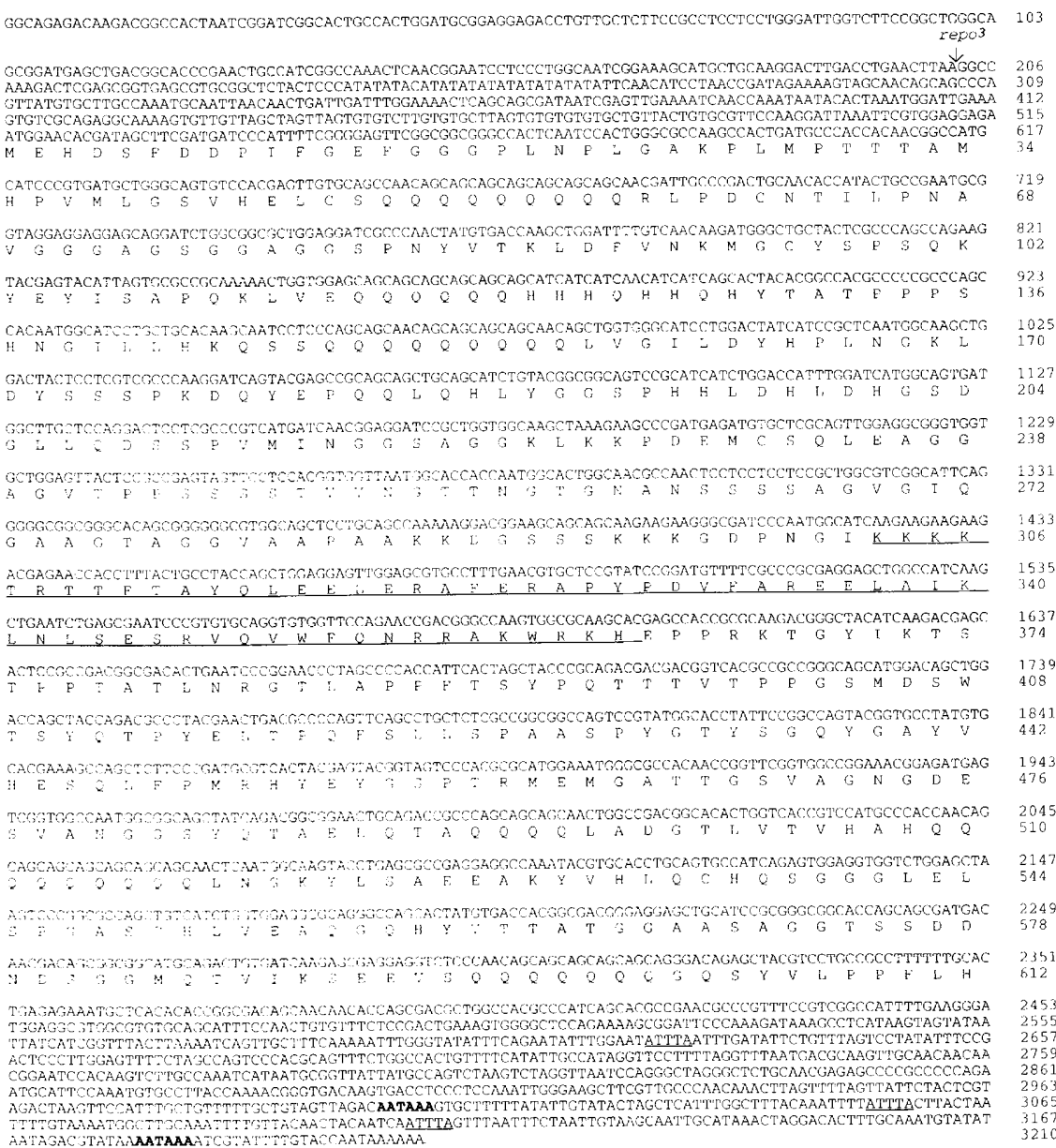

B

REPO KKKKTRTTFT AYQLEELERA FERAPYPDVF AREELAIKLN LSESRVQVWF QNRRAKWRKH 60

UNC-4 -RRR---N-S GW--.--S- --ASH---.- M--A--MR-D -L---.-. -

$\mathrm{AL}$ -QRRY---- SF-----K- -S-TH----- T--.--M-IG -T-A-I--- -

PAX-3

PRD -QRRS--.-- -E---

PAX[Zf-a]/AN -LQRN--S-- QE-I-A--KE ---TH---- ---R--A-ID -P-A-I---- S-------RE 37

$\begin{array}{lll}\text { /SEY/PAX-6 } & \text {-LRRE----- RA--DV--AL -GKTR---I- M---V-L-I- -P------- K-----C-QQ } 36 \\ \text { OTD } & \text { O }\end{array}$

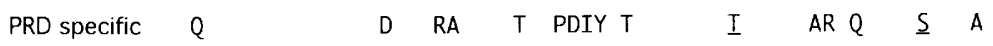

margin of each segment just behind the segmental border labeled by an anti-ENGRAILED (EN) antibody (Fig. 10C). Following the initial detection of repo expression, the GB divided once symmetrically to produce two progeny (Fig. 10D) A third repo-expressing cell was detected medial to the first pair in the ventral view of stage $11 \mathrm{em}$ bryos (Fig. 10E). This third cell was first observed in the abdominal segments and later in the thoracic segments during stage 12 (data not shown). During stage 12 of embryogenesis, there were two clusters of cells, located posterior and anterior to the segmental border labeled by the anti-EN antibody (Fig. 10F,G). By the germ-band retraction stage, there were numerous longitudinal glia in ev- ery hemisegment. Although the exact number was difficult to determine (Fig. 10H,I), it was in excess of the six reported previously (Jacobs et al. 1989).

\section{Discussion}

repo encoded a glial-specific prd-like homeo domain protein

Many known homeo box genes, such as Ultrabithorax, Antennapedia, prd, ftz, and en in Drosophila (Hayashi and Scott 1990; McGinnis and Krumlauf 1992) and the Hox-type homeo box genes in vertebrates (McGinnis and 

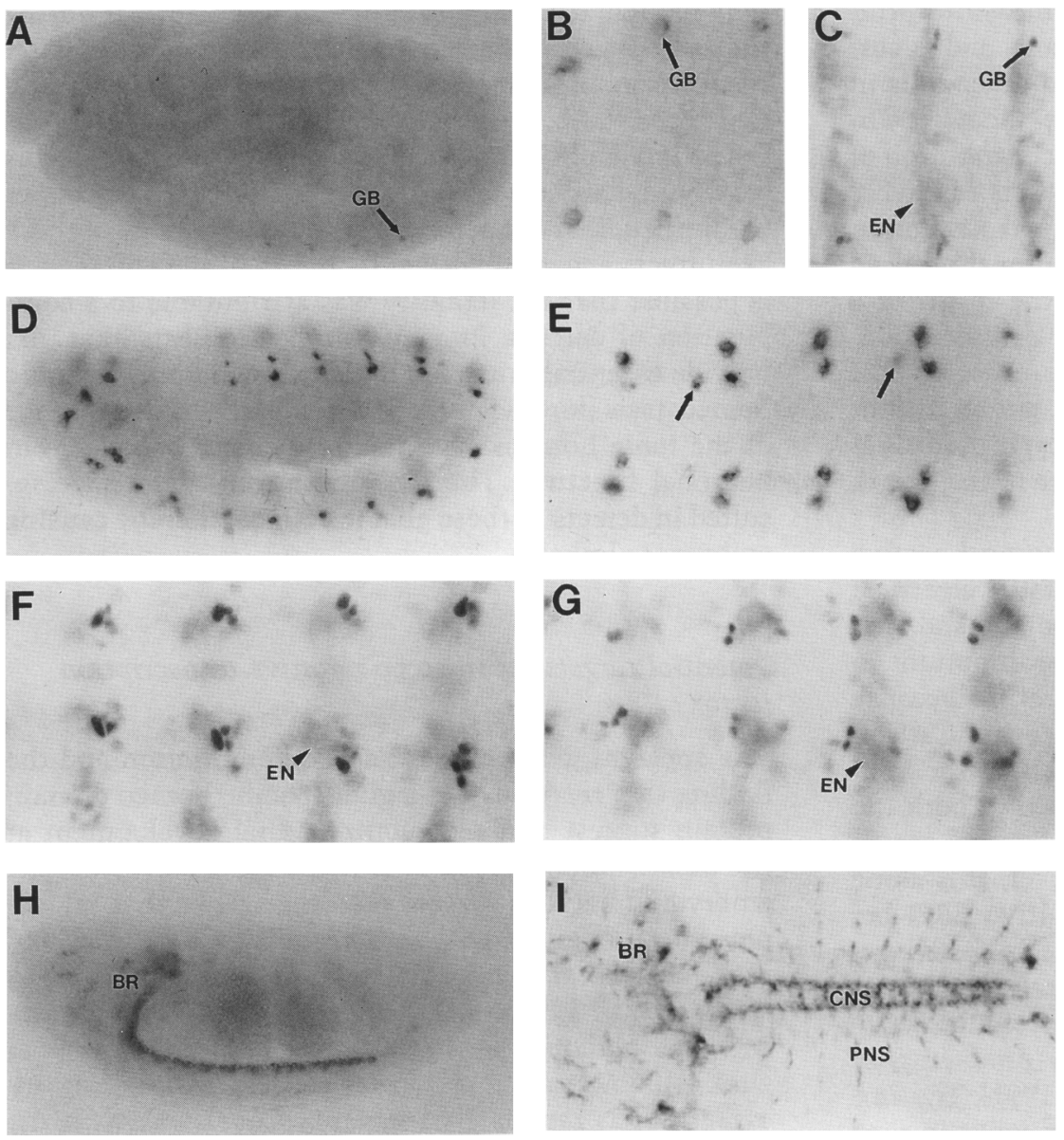

Figure 10. repo spatial expression pattern in embryos at different stages of development. $\{A, B, D, E, H, I\}$ repo RNA expression detected by in situ hybridization to wholemount embryos. $(C, F, G)$ repo ${ }^{4}$ heterozygous embryos double-labeled with anti- $\beta$ galactosidase (black) and anti-EN antibodies (gray). Embryos were oriented with anterior to the left. (A) Stage 9 embryo (lateral view), arrow points to glioblast (GB); $(B)$ higher magnification of a ventral view in the abdominal region of a stage $9 \mathrm{em}-$ bryo; $(C)$ higher magnification of a ventral view of a double-labeled stage 9 embryo, EN antibody staining is indicated; $(D)$ lateral view of a stage 11 embryo; $(E)$ ventral view in the abdomen region of a stage 11 embryo, arrows point to the third cell present in every abdominal segment but seen in only in some segments in this view, as it is in a focal plane different from the other two cells; $(F)$ ventral view of a stage 12 double-labeled embryo; $(G)$ ventral view of the same embryo as in $F$ in a different focal plane; $(H)$ lateral view of a stage 15 embryo; $(I)$ ventral view of a stage 15 embryo. (BR) Brain.
Krumlauf 1992|, appear to convey positional information rather than regulate the specification of individual cell types. There are also many homeo box genes whose expression is tissue specific. Examples include several members of vertebrate POU gene family (Pit-1, Brn-1, Brn-2, and Brn-3) that are expressed specifically in the developing CNS (Ingraham et al. 1988; He et al. 1989). The repo homeo box gene, whose expression was restricted to specific glial cell lineages, is a candidate for a cell-type specification gene.

Homeo domain genes have been grouped into 10 families on the basis of the relatedness of the 60-amino-acid homeo box (Scott et al. 1989). Among these classes, the REPO homeo domain was most similar to the PRD-like group (Schneitz et al. 1993). REPO did not contain other sequences frequently conserved among PRD-like proteins, such as a PRD box (Bopp et al. 1986). Therefore, REPO appears to be a PRD-like rather than PRD-type homeo domain protein.

\section{repo appeared to be required for glial development} in the visual system and embryonic nervous system

repo is a glial-specific homeo domain protein suggesting that it might be important for glial development. Examination of the expression of glial markers in the developing repo visual system in the third-instar larvae indi- cated that the glia began to develop but did not terminally differentiate. No significant difference in the number of glial cells labeled by the glial-specific lac $Z$ enhancer trap line 3-109 or the repo lac $Z$ was observed between wild type and repo. However, glial expression of OTD was eliminated. In the adult visual system, expression of neither the 3-109 lacZ nor the OTD protein was detected. The absence of this staining did not appear to be attributable to missing glia in young repo adults because the normal number of cells in repo homozygotes expressed the repo lacZ. The repo lacZ-positive cells did not express a neuronal marker and therefore did not appear to be transformed into a neural cell fate. In the embryo, the repo gene product was also expressed specifically in glia. These included most glial cell types identified previously except the midline glia. The pattern of repo lacZ expression was similar in repo and wild type; however, OTD was not detected in the repo expressing glia. These observations suggested that the glia in the embryo and visual system had only partially differentiated.

repo ERG phenotype appears to be attributable to defects in glia in the visual system

The failure of many glial cells in the adult visual system to differentiate fully had a major effect on the waveform 
of the ERG. In wild-type flies, the ERG measures principally the light response of the retinal cells and is corneal negative. The response of the second-order cells in the lamina to light is corneal positive (Shaw 1975; Stephenson and Pak 1980). However, the contribution of the laminal response to the wild-type ERG is relatively minor, presumably attributable to electrical insulation between the retina and lamina. The corneal-positive ERG in repo flies did not appear to be the result of a defect in the regulation of photoreceptor cell ion channels, or any other disruption in the photoreceptor cells, because intracellular recordings of repo photoreceptor cells were indistinguishable from wild type. Additionally, the repo gene was not expressed in the retina, but in the subretinal glia and laminal glia.

A possible explanation for the repo corneal-postive ERG is that there may have been defects in electrical insulation and $\mathrm{K}^{+}$buffering. The satellite glia and subretinal cells are the glia most likely to be important in electrically insulating the lamina and retina because they separate these two layers (Saint Marie and Carlson 1983). In the absence of the normal insulation, the ERG would presumably measure the summation of both the corneal-negative retinal potential and the laminal potential, which is of opposite polarity. However, this alone would not fully explain the comeal-positive ERG because the amplitude of the laminal corneal-positive response is not larger than the retinal corneal-negative response (Stephenson and Pak 1980). Glial cells in vertebrates have been shown to buffer $\mathrm{K}^{+}$by producing an inward $\mathrm{K}^{+}$current (for review, see Barres 1991). The amplitude of the laminal corneal-positive response in repo could be larger than in wild type because of the failure of laminal glia to buffer the $\mathrm{K}^{+}$released by the laminal neurons (for review, see Nicholls et al. 1992). Consistent with this proposal, we have found that the amplitude of the laminal response in repo was more than twice as large as that in wild-type flies (W.-C. Xiong and C. Montell, unpubl.). Thus, it is possible that the reversed-polarity ERG observed in repo might have resulted from a combined deficiency in $\mathrm{K}^{+}$buffering and electrical insulation.

\section{repo embryonic phenotype appears to be attributable} to defects in glia

Because repo was expressed specifically in glia and there was an apparent disruption of glial differentiation, the embryonic lethality in the strongest repo alleles appeared to be caused by defects in glia. The thinning in the longitudinal connectives in some repo/Df(3R)P14 embryos suggests that condensation of these axon tracts may be affected by a failure in terminal differentiation of the longitudinal glia. The formation of these axon tracts was probably not affected in repo embryos as breaks were not detected between any segments. However, these results do not exclude a role for the longitudinal glia during formation of the longitudinal axon tracts as suggested previously (Jacobs and Goodman 1989) because the repo longitudinal glia appeared to be normal during the early stages of development when the pioneer axon tracts form (Bastiani and Goodman 1986; Jacobs and Goodman 1989).

The late embryonic lethality in the strong repo alleles may not have been attributable exclusively to defects in the longitudinal connectives, as the morphology of these axon tracts appeared normal in $>50 \%$ of the embryos. It is possible that the lethality was attributable to a combination of defects. Previous studies indicate that glia provide essential nutrients to neurons and provide ionic homeostasis (for review, see Barres 1991). In the absence of the ionic homeostasis, there appear to be defects in neuronal function. The repo mutation might have resulted in defects in these glial functions, thereby causing embryonic lethality.

\section{Potential targets for the repo putative transcription factor}

The apparent defect in glial cell differentiation and the finding that repo encodes a glial-specific homeo domain protein suggest that repo controls glial development at the transcriptional level. Potential targets for repo in the embryonic nervous system are other genes that are expressed in longitudinal glia. These include $f t z$, otd, and pros (Doe et al. 1988, 1991; Finkelstein et al. 1990; Vaessin et al. 1991; Wieschaus et al. 1992). These genes could be potential targets for repo in the longitudinal glial cells but not in all of the cells in which they are expressed, as repo is glial-specific. Consistent with the proposal that otd might be a target for repo in the embryonic nervous system, expression of OTD initiated subsequent to repo (Xiong and Montell, unpubl.) and, in the repo mutant, was absent in those glia in which repo was normally expressed.

The otd gene is also a potential target for repo in glial cells in the visual system, as otd was not expressed in repo subretinal cells. The 3-109 lacZ marker is not a likely candidate for transcriptional regulation by REPO, as 3-109 was expressed in repo larvae. Several other genes have been identified that are expressed either specifically in glia (anachronism) or in both neurons and glial cells in the visual system (cut, tramtrack and optomotor-blind) (Blochlinger et al. 1993; Ebens et al. 1993; Poeck et al. 1993; Xiong and Montell 1993). It is possible that repo regulates the expression of one or more of these genes.

\section{Materials and methods}

\section{Electrophysiology}

ERG recordings were performed by inserting glass electrodes, filled with Ringer's solution, in small drops of electrode cream placed on the surface of the compound eye and thorax as described previously (Porter et al. 1992). Intracellular recordings were performed by placing a low-resistance electrode, containing Ringer's solution, into a small hole in the compound eye and a reference electrode on the thorax as described previously 
(Barash et al. 1988). Recordings were performed on flies $<7$ days posteclosion.

\section{Fly stocks and genetics}

The repo ${ }^{1}$ mutant was identified among $\sim 7000$ homozgous viable P-element lines screened by performing ERGs. In A.S. Spradling's laboratory (Karpen and Spradling 1993), 6000 lines were generated, 400 homozygous P-element insertion lines were kindly provided by M.C. Mullins, and an additional 400 lines were a gift of M.E. Fortini (both from University of California, Berkeley). The repo ${ }^{1}$ mutant was found among the Mullins lines, which contained a single modified P-element consisting of a rosy ${ }^{+}+\left(r y^{+}\right)$gene and a copy of the chloramphenicol acetyltransferase (CAT) reporter gene (Mullins et al. 1989). The repo $^{2}$, repo $^{3}$, and repo ${ }^{4}$ alleles were identified among the collection of homozygous lethal P-element insertion lines from the Spradling laboratory (stocks 3702,692 , and 2138 respectively; Karpen and Spradling 1992). The repo ${ }^{4}$ allele was also identified in a screen of the P-element lethal lines for mutations affecting neural development (N. Patel, unpubl.). To demonstrate that the $\mathrm{P}$ element induced the repo mutation, the $\mathrm{P}$ element from repo ${ }^{1}$ and repo ${ }^{4}$ was mobilized by crossing repo flies with a stock, referred to as jumpstarter or $\Delta 2-3$, which provided the P-element transposase required in trans for transposition. Among $59 \mathrm{ry}^{-}$lines that were established from repo ${ }^{1}, 26$ reverted to wild type, 5 were recessive lethals, and 28 were semilethal or homozygous viable lines that exhibited a repo ERG phenotype. One of these lines that exhibited a repo ERG phenotype, repo ${ }^{1 e 44}$, was used in the analysis of 3-109 expression in the developing and adult visual system, as the $r y^{-}$background facilitated genetically introducing the 3-109 $\mathrm{ry}^{+}$element into a repo background. Among $40 \mathrm{ry}^{-}$lines that were established from repo ${ }^{4}, 22$ reverted to wild type and 18 were recessive lethals. repo $4 e 19$ and repo ${ }^{4 e 25}$ were two of the lethal lines obtained by mobilization of the repo ${ }^{4} \mathrm{P}$ element. The deletion in repo ${ }^{4 e 19}$ was mapped by digesting the genomic DNA with NarI and probing the DNA blot with a PstI-NarI fragment cDNA fragment (nucleotides 1366-1905). The wild-type NarI genomic fragment, which hybridizes to the cDNA probe, encodes REPO amino acids 23-465. The breakpoints of $D f(3 R) P 14$ are 90C2-D1 and 91A2-3 (Detwiler and MacIntyre 1978).

\section{Immunolocalizations, histochemical localizations, and in situ hybridizations}

Antibody staining was performed as described previously (Patel et al. 1989). The fixation was done either in $4 \%$ formaldehyde for $15 \mathrm{~min}$ (whole-mount embryos) or in $2 \%$ paraformaldehyde for $45 \mathrm{~min}(8 \mu \mathrm{M}$ frozen sections of adult fly heads, wholemount eye discs, larval brain, and CNS). Rat polyclonal antiOTD (1:50), rabbit polyclonal anti- $\beta$-galactosidase $(1: 5000)$, and the following mouse monoclonal antibodies were used: anti- $\beta$ galactosidase (1:1000; Promega); 22C10 (1:10); BP102 (1:10); anti-ELAV (1:5); and anti-EN (1:10). HRP-conjugated secondary antibodies were developed with $0.5 \mathrm{mg} / \mathrm{ml}$ of diaminobenzidine (DAB) and $0.03 \%$ hydrogen peroxide. Immunofluorescent local. izations were performed with FITC- and RITC-conjugated secondary antibodies and were viewed by confocal microscopy. Identical anti- $\beta$-galactosidase staining patterns were obtained with repo ${ }^{2}$, repo ${ }^{3}$, and repo ${ }^{4}$ heterozygotes /which contained $\mathrm{P}[$ lacZ $]$ enhancer trap $\mathrm{P}$ elements) except that the embryonic expression initiated in repo $o^{4}$ during stage 9 and in repo ${ }^{2}$ and repo $o^{3}$ during stage 13 . repo ${ }^{1}$ flies were not examined for $\beta$-galactosidase staining because the $P$ element that was used to generate this allele did not contain a lacZ reporter gene (Mullins et al. 1989). Histochemical staining of eye discs and sections of adult heads for lac $Z$ activity were done as described (Winberg et al. 1992). Localization of RNA in whole-mount embryos was performed using single-strand polymerase chain reaction (PCR)generated, digoxigenin-labeled probes prepared (Patel and Goodman 1992) from the repo cDNA.

\section{Isolation and analyses of repo genomic and CDNA clones}

The initial repo genomic DNA clone was isolated from a repo ${ }^{1}$ DNA library probed with the $5^{\prime}$-P-element end. The library was constructed by digesting repo ${ }^{1}$ genomic DNA with EcoRI, fractionating DNA in the 3- to $5-\mathrm{kb}$ range from an agarose gel, and cloning into $\lambda$ gt 11 . The repo ${ }^{1}$ genomic DNA was used to screen a wild-type genomic DNA library inserted into bacteriophage $\lambda$, Charon 4A (Maniatis et al. 1978). One of the genomic clones, Arepo-1, contained a 14.5-kb insert (0-14.5 map units, Fig. 7) and was used to construct most of the physical map. The DNA sequences flanking the P-element insertion sites of $r e \mathrm{po}^{2}$, repo ${ }^{3}$, and repo ${ }^{4}$ were recovered by the plasmid rescue technique (Pirrotta 1986). The genomic DNA isolated from repo ${ }^{2}$ and repo ${ }^{3}$ was used to extend the physical map to the $X b a I$ site at $\sim 17$ map units (Fig. 7).

Two overlapping cDNAs, pcrepo-2.6 (nucleotides 1-2552) and pcrepo-2.2 (nucleotides 985-3210), were isolated from an embryonic cDNA library probed with a ${ }^{32} \mathrm{P}$-labeled $3.5-\mathrm{kb}$ genomic region as described (Montell and Rubin 1989). The cDNAs were sequenced by the dideoxy chain termination method using Sequenase (U.S. Biochemical). The template DNAs used for the DNA sequencing were generated by subcloning random cDNA fragments, generated as described (Montell and Rubin 1989), into the SmaI site of M13mplo.

\section{Mapping P-element insertion sites}

The position and orientation of the P-element insertion in repo ${ }^{1}$ was determined by probing a Southern blot containing DNA prepared from wild-type and mutant flies with P-element sequences as well as flanking repo genomic DNA. The sites of the P-element insertions in the three lethal alleles, repo ${ }^{2}$, repo ${ }^{3}$, and repo $^{4}$, were determined by isolating the flanking genomic DNA, by the plasmid rescue technique, and sequencing genomic DNA from the insertion lines, using a primer that hybridized to the $5^{\prime}$ end of the P element.

\section{Mapping repo-transcribed region and RNA blots}

The approximate genomic region encoding the $3.5-\mathrm{kb}$ repo mRNA was initially determined by digesting the cloned repo genomic DNA with various restriction enzymes, transferring to GeneScreen Plus, (NEN) and probing with ${ }^{32} \mathrm{P}$-labeled cDNAs prepared from adult RNA. The transcribed region was mapped in greater detail by probing blots containing the cloned genomic DNA with the cDNAs pcrepo-2.6 and pcrepo-2.2. To perform RNA blots, total RNA was prepared as described (Montell and Rubin 1989), transferred to GeneScreen Plus and probed with a 0.6-kb PstI fragment of the repo cDNA (nucleotides 1365-1985) labeled with ${ }^{32} \mathrm{P}$.

\section{Acknowledgments}

We thank Drs. R. Finkelstein, Y.N. Jan, and S. Benzer for antibodies, Dr. C.S. Goodman for the 3-109 glial enhancer trap line, Drs. A.S. Spradling, M.C. Mullins, and M.E. Fortini for provid- 
ing the P-element insertion lines, and Irina Orlov for technical assistance with the embryonic antibody staining. We are grateful to A. Perertz and Dr. B. Minke for checking repo ${ }^{1}$ flies by intracellular recordings. We also thank Drs. P.A. Beachy and D.J. Montell for helpful comments on the manuscipt. This work was supported by a National Institutes of Health postdoctoral fellowship to J.A.B. and a grant from the American Cancer Society (NP-798) to C.M. C.M. also acknowledges support from a National Science Foundation Presidential Young Investigator Award and an American Cancer Society Junior Faculty Research Award. N.H.P. was supported by grants from the McKnight Endowment Fund for Neuroscience and the National Institutes of Health.

The publication costs of this article were defrayed in part by payment of page charges. This article must therefore be hereby marked "advertisement" in accordance with 18 USC section 1734 solely to indicate this fact.

\section{Note added in proof}

The sequence data described in this paper have been submitted to the EMBL data library under accession number X78218.

\section{References}

Barash, S.E., E. Suss, D.G. Stavenga, C.T. Rubinstein, Z. Selinger, and B. Minke. 1988. Light reduces the excitation-efficiency in the nss mutant of the sheep blowfly Lucilia. J. Gen. Physiol. 92: 307-330.

Barres, B.A. 1991. New roles for glia. J. Neurosci. 11: 3685-3694.

Bastiani, M.J. and C.S. Goodman. 1986. Guidance of neuronal growth cones in the grasshopper embryo. III. Recognition of specific glial pathways. I. Neurosci. 6: 3542-3551.

Bier, E., L. Ackerman, S. Barbel, L. Jan, and Y.N. Jan. 1988. Identification and characterization of a neuron-specific nuclear antigen in Drosophila. Science 240: 913-916.

Bier, E., L.Y. Jan, and Y.N. Jan. 1990. rhomboid, a gene required for dorsoventral axis establishment and peripheral nervous system development in Drosophila melanogaster. Genes \& Dev. 4: 190-203.

Blochlinger, K., L.Y. Jan, and Y.N. Jan. 1993. Postembryonic patterns of expression of cut, a locus regulating sensory organ identity in Drosophila. Development 117: 441-450.

Bopp, D., M. Burri, S. Baumgartner, G. Frigerio, and M. Noll. 1986. Conservation of a large protein domain in the segmentation gene paired and in functionally related genes of Drosophila. Cell 47: 1033-1040.

Buchanan, R.L. and S. Benzer. 1993. Defective glia in the Drosophila brain degeneration mutant drop-dead. Neuron 10: $839-850$.

Buchner, E. 1991. Genes expressed in the adult brain of Drosophila and effects of their mutations on behavior: a survey of transmitter- and second messenger-related genes. I. Neurogenet. 7: 153-192.

Cagan, R.L. and D.F. Ready. 1989. The emergence of order in the Drosophila pupal retina. Dev. Biol. 136: 346-362.

Cameron, S. and P. Rakic. 1991. Glial cell lineage in the cerebral cortex: a review and synthesis. Glia 4: 124-137.

Carlson, S.D. and R.L. Sainte Marie. 1990. Structure and function of insect glia. Annu. Rev. Entomol. 35: 597-621.

Crews, S.T., J.B. Thomas, and C.S. Goodman. 1988. The Drosophila single-minded gene encodes a nuclear protein with sequence similarity to the per gene product. Cell 752: 143151.

Detwiler, C. and R. MacIntyre. 1978. A genetic and developmental analysis of an acid deoxyribonuclease in Drosophila melanogaster. Biochem. Genet. 16: 1113-1134.
Doe, C.Q., Y. Hiromi, W.J. Gehring, and C.S. Goodman. 1988. Expression and function of the segmentation gene fushi tarazu during Drosophila neurogenesis. Science 239: 170175.

Doe, C.Q., Q. Chu-LaGraff, D.M. Wright, and M.P. Scott. 1991. The prospero gene specifies cell fates in the Drosophila central nervous system. Cell 65: 451-464.

Doucette, R. 1990. Glial influences on axonal growth in the primary olfactory system. Glia $3: 433-449$.

Ebens, A.J., H. Garren, B.N.R. Cheyette, and S.L. Zipursky. 1993. The Drosophila anachronism locus: a glycoprotein secreted by glia inhibits neuroblast proliferation. Cell 74: $15-$ 27.

Eccleston, P.A. 1992. Regulation of Schwann cell proliferation: Mechanisms involved in peripheral nerve development. Exp. Cell Res. 199: 1-9.

Fawcett, J.W. and R.J. Keynes. 1990. Peripheral nerve regeneration. Annu. Rev. Neurosci. 13: 43-60.

Finkelstein, R., D. Smouse, T.M. Capaci, A.C. Spradling, and N. Perrimon. 1990. The orthodenticle gene encodes a novel homeo domain protein involved in the development of the Drosophila nervous system and ocellar visual structures. Genes \& Dev. 4: 1516-1527.

Fredieu, J.R. and A.P. Mahowald. 1989. Glial interactions with neurons during Drosophila embryogenesis. Development 106: $739-748$.

Frigerio, G., M. Burri, D. Bopp, S. Baumgartner, and M. Noll. 1986. Structure of the segmentation gene paired and the Drosophila PRD gene set as part of a gene network. Cell 47: 735-746.

Giangrande, A., M.A. Murray, and J. Palka. 1993. Development and organization of glial cells in the peripheral nervous system of Drosophila melanogaster. Development 117: 895904.

Goldman, J.E. and P.J. Vaysse. 1991. Tracing glial cell lineages in the mammalian forebrain. Glia 4: 149-156.

Goulding, M.D., G. Chalepakis, U. Deutsch, J. Erselius, and P. Gruss. 1991. Pax-3, a novel murine DNA binding protein expressed during early neurogenesis. $E M B O \quad J$. 10: 11351147.

Hanes, S.D. and R. Brent. 1989. DNA specificity of the bicoid activator protein is determined by homeodomain recognition helix residue 9. Cell 57: 1275-1283.

Hatten, M.E., R.K. Liem, M.L. Shelanski, and C.A. Mason. 1991. Astroglia in CNS injury. Glia 4: 233-243.

Hayashi, S. and M.P. Scott. 1990. What determines the specificity of action of Drosophila homeodomain proteins? Cell 63: 883-894.

He, X., M.N. Treacy, D.M. Simmons, H.A. Ingraham, L.W. Swanson, and M. Rosenfeld. 1989. Expression of a large family of POU-domain regulatory genes in mammalian brain development. Nature 340: 35-41.

Ingraham, H.A., R. Chen, H.J. Mangalam, H.P. Elsholtz, S.E. Flynn, C.R. Lin, D.M. Simmons, L. Swanson, and M.G. Rosenfeld. 1988. A tissue-specific transcription factor containing a homeodomain specifies a pituitary phenotype. Cell 55: 519-529.

Jacobs, J.R. and C.S. Goodman. 1989. Embryonic development of axonal pathways in the Drosophila CNS. I. A glial scaffold appears before the first growth cones. J. Neurosci. 9: 24022411 .

Jacobs, J.R., Y. Hiromi, N.H. Patel, and C.S. Goodman. 1989. Lineage, migration, and morphogenesis of longitudinal glia in the Drosophila CNS as revealed by a molecular lineage marker. Nature 2: 1625-1631.

Jessen, K.R. and R. Mirsky. 1992. Schwann cells: Early lineage, 
regulation of proliferation and control of myelin formation. Curr. Opin. Neurobiol. 2: 575-581.

Jostes, B, C. Walther, and P. Gruss. 1991. The murine paired box gene, $\mathrm{Pax} 7$, is expressed specifically during the development of the nervous and muscular system. Mech. Dev. 33: 27-37.

Karpen, G.H. and A.S. Spradling. 1992. Analysis of subtelomeric heterochromatin in Drosophila minochromosome Dp1187 by single $\mathrm{P}$ element insertion mutagenesis. Genetics 132: 737-752.

Klämbt, C. 1993. The Drosophila gene pointed encodes two ETS-like proteins which are involved in the development of the midline glial cells. Development 117: 163-176.

Klämbt, C. and C.S. Goodman. 1991. The diversity and pattern of glia during axon pathway formation in the Drosophila embryo. Glia 4: 205-213.

Klämbt, C., J.R. Jacobs, and C.S. Goodman. 1991. The midline of the Drosophila central nervous system: A model for the genetic analysis of cell fate, cell migration, and growth cone guidance. Cell 64: 801-815.

Klämbt, C., L. Glazer, and B.-Z. Shilo 1992. breathless, a Drosophila FGF receptor homolog, is essential for migration of tracheal and specific midline glial cells. Genes \& Dev. 6: $1668-1678$.

Krauss, S., T. Johansen, V. Korzh, U. Moens, J.U. Ericson, and A. Fjose. 1991. Zebrafish pax[zf-a]: A paired box-containing gene expressed in the neural tube. EMBO J. 10: 3609-3619.

Le Douarin, N., C. Dulac, E. Dupin, and P. Cameron-Curry. 1991. Glial cell lineages in the neural crest. Glia 4: 175-184.

Maniatis, T., R.C. Hardison, E. Lacy, J. Lauer, C. O'Connell, D. Quon, G.K. Sim, and A. Efstratiadis. 1978. The isolation of structural genes from libraries of eucaryotic DNA. Cell 15: $687-701$.

Marchionni, M.A., A.D.J. Goodearl, M.S. Chen, O. Bermingham-McDonogh, C. Kirk, M. Henricks, F. Danehy, D. Misumi, J. Sudhalter, K. Kobayashi, D. Wroblewski, C. Lynch, M. Baldassare, I. Hiles, J.B. Davis, J.J. Hsuan, N.F. Totty, M. Otsu, R.N. McBurney, M.D. Waterfield, P. Stroobant, and D. Gwynne. 1993. Glial growth factors are alternatively spliced erbB2 ligands expressed in the nervous system. Nature 362: 312-318.

Masu, Y., E. Wolf, B. Holtmann, M. Sendtner, G. Brem, and H. Thoenen. 1993. Disruption of the CNTF gene results in motor neuron degeneration. Nature 365: 27-32.

McGinnis, W. and R. Krumlauf. 1992. Homeobox genes and axial patterning. Cell 68: 283-302.

Miller, D.M, M.M. Shen, C.E. Shamu, T.R. Bürglin, G. Ruvkun, M.L. Dubois, M. Ghee, and L. Wilson. 1992. C. elegans unc-4 gene encodes a homeodomain protein that determines the pattern of synaptic input to specific motor neurons. Nature 355: $841-845$.

Minke, B. and Z. Selinger. 1992. Intracellular messengers in invertebrate photoreceptors studied in mutant flies. In Neuromethods (ed. A. Boulton, G. Baker, and C. Taylor), pp. 517-563. The Humana Press, Clifton, NT.

Montell, C. 1989. Molecular genetics of Drosophila vision. BioEssays 11: 43-48.

Montell, C. and G.M. Rubin. 1989. Molecular characterization of the Drosophila trp locus: A putative integral membrane protein required for phototransduction. Neuron 2: 13131323.

Mullins, M.C., D.C. Rio, and G.M. Rubin. 1989. Cis-acting DNA sequence requirements for P-element transposition. Genes \& Dev. 3: 729-738.

Nambu, J.R., R.G. Franks, S. Hu, and S.T. Crews. 1990. The single-minded gene of Drosophila is required for the expression of genes important for the development of CNS midline cells. Cell 63: 63-75.

Nicholls, J.G., A.R. Martin, and B.G. Wallace. 1992. Properties and functions of neuroglial cells. In From neuron to brain. pp. 148-183. Sinauer Associates, Sunderland, MA.

Patel, N.H. and C.S. Goodman. 1992. DIG-labeled singlestranded DNA probes for in situ hybridization. In Nonradioactive labeling and detection of biomolecules /ed. C. Kessler), pp. 377-381. Springer Verlag, Berlin, Germany.

Patel, N.H., E. Martin-Blanco, K.G. Coleman, S.J. Poole, M.C. Ellis, T.M. Kornberg, and C.S. Goodman. 1989. Expression of engrailed proteins in arthropods, annelids and chordates. Cell 58: 955-968.

Pirrotta, V. 1986. Cloning Drosophila genes. In Drosophila, a practical approach. (ed. D.R. Roberts), pp. 83-110. IRL Press, Oxford/Washington D.C.

Poeck, B., A. Hofbauer, and G.O. Pflugfelder. 1993. Expression of the Drosophila optomotor-blind gene transcript in neuronal and glial cells of the developing nervous system. Development 117: 1017-1029.

Porter, J.A., J.L. Hicks, D.S. Williams, and C. Montell. 1992. Differential localizations of and requirements for the two Drosophila ninaC kinase/myosins in photoreceptor cells. J. Cell Biol. 116: 683-693.

Raff, M.C. 1989. Glial cell diversification in the rat optic nerve Science 243: 1450-1455.

Rakic, P. 1971. Neuron-glia relationship during granule cell migration in developing cerebellar cortex. A golgi and electron microscopic study in Macacus rhesus. I. Comp. Neurol. 141: 283-312.

Robinow, S. and K. White. 1988. The locus elav of Drosophila melanogaster is expressed in neurons at all developmental stages. Dev. Biol. 126: 294-303.

Roitbak, A.I. 1983. Neuroglia. Fisher Verlag, Berlin, Germany.

Rothberg, J.M., J.R. Jacobs, C.S. Goodman, and S. ArtavanisTsakonas. 1990. slit: An extracellular protein necessary for development of midline glia and commissural axon pathways contains both EGF and LRR domains. Genes \& Dev. 4: 2169-2187.

Rutledge, B.J., K. Zhang, E. Bier, Y.N. Jan, and N. Perrimon. 1992. The Drosophila gene spitz encodes a putative EGF-like growth factor involved in dorsal-ventral axis formation and neurogenesis. Genes \& Dev. 6: 1503-1517.

Saint Marie, R.L. and S.D. Carlson. 1983. The fine structure of neuroglia in the lamina ganglionaris of the housefly, Musca domestica L. J. Neurocytology 12: 213-241.

Schneitz, K., P. Spielman, and M. Noll. 1993. Molecular genetics of aristaless, a prd-type homeo box gene involved in the morphogenesis of proximal and distal pattern elements in a subset of appendages in Drosophila. Genes \& Dev. 7: 114 129 .

Scott, M.P., J.W. Tamkun, and G.W. Hartzell III. 1989. The structure and function of the homeodomain. Biochem. Biophys. Acta 989: 25-48.

Shaw, G. and R. Kamen. 1986. A conserved AU sequence from the $3^{\prime}$ untranslated region of GM-CSF mRNA mediates selective mRNA degradation. Cell 46: 659-667.

Shaw, S.R. 1975. Retinal resistance barriers and electrical lateral inhibition. Nature 255: 480-483.

-1977. Restricted diffusion and extracellular space in the insect retina. J. Comp. Physiol. 113: 257-282.

Silver, J. and U. Rutishauser. 1982. Guidance of optic axons in vivo by a pre-formed adhesive pathway on neuro-epithelial endfeet. Dev. Biol. 106: 485-499.

Silver, J., S.E. Lorenz, D. Wahlstein, and J. Coughlin. 1982. Axonal guidance during development of the great cerebral commissures: Descriptive and experimental studies in vivo on 
the role of preformed glial pathways. J. Comp. Neurol. 210: $10-29$.

Smith, D.P., M.A. Stamnes, and C.S. Zuker. 1991. Signal transduction in the visual system of Drosophila. Annu. Rev. Cell Biol. 7: 161-190.

Stephenson, R.S. and W.L. Pak. 1980. Heterogenic components of a fast electrical potential in Drosophila compound eye and their relation to visual pigment photoconversion. I. Gen. Physiol. 75: 353-379.

Stitt, T.N., U.E. Gasser, and M.E. Hatten. 1991. Molecular mechanisms of glial-guided neuronal migration. Ann. N.Y. Acad. Sci. 633: 113-121.

Thomas, J.B., S.T. Crews, and C.S. Goodman 1988. Molecular genetics of the single-minded locus: A gene involved in the development of the Drosophila nervous system. Cell 52: 133-141.

Ton, C.C.T., H. Hirvonen, H. Miwa, M.M. Weil, P. Monaghan, T. Jordan, V. van Heyningen, N.D. Hastie, H. Meijers-Heijboer, M. Drechsler, B. Royer-Pokora, F. Collins, A. Swaroop, L.C. Strong, and G.F. Saunders. 1991. Positional cloning and characterization of a paired box- and homeobox-containing gene from the Aniridia region. Cell 67: 1059-1074.

Treisman, J., P. Gonczy, M. Vashishtha, E. Harris, and C. Desplan. 1989. A single amino acid can determine the DNA binding specificity of homeodomain proteins. Cell 59: 553562.

Trujillo-Cenoz, O. and J. Mekamed. 1973. The development of the retina-lamina complex in muscoid flies. $/$. Ultrastruct. Res. 42: 554-581.

Udolph, G., A. Prokop, T. Bossing, and G.M. Technau. 1993. A common precursor for glia and neurons in the embryonic CNS of Drosophila gives rise to segment-specific lineage variants. Development 118: 765-775.

Vaessin, H., E. Grell, E. Wolff, L.Y. Jan, and Y.N. Jan. 1991. prospero is expressed in neuronal precursors and encodes a nuclear protein that is involved in the control of axonal outgrowth in Drosophila. Cell 67: 941-953.

Vernadakis, A. 1988. Neuron-glia interactions. Int. Rev. Neurobiol. 30: 149-224.

Walther, C. and P. Gruss. 1991. Pax-6, a murine paired box gene, is expressed in the developing CNS. Development 113: 1435-1449.

Wharton, K.A., B. Yedvibnick, V.G. Finnerty, and S. ArtavanisTsakonas. 1985. opa: A novel family of transcribed repeats sheared by the Notch locus and other developmentally regulated loci in D. melanogaster. Cell 43: 567-581.

Wieschaus, E., N. Perrimon, and R. Finkelstein. 1992. orthodenticle activity is required for the development of medial structures in the larval and adult epidermis of Drosophila. Development 115: 801-811.

Winberg, M.L, S.E. Perez, and H. Steller. 1992. Generation and early differentiation of glial cells in the first optic ganglion of Drosophila melanogaster. Development 115: 903-911.

Xiong, W.-C. and C. Montell. 1993. tramtrack is a transcriptional repressor required for cell fate determination in the Drosophila eye. Genes \& Dev. 7: 1085-1096. 


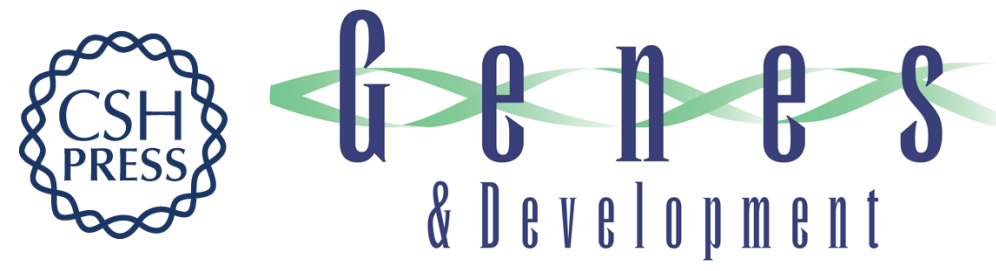

\section{repo encodes a glial-specific homeo domain protein required in the Drosophila nervous system.}

W C Xiong, H Okano, N H Patel, et al.

Genes Dev. 1994, 8:

Access the most recent version at doi:10.1101/gad.8.8.981

References This article cites 82 articles, 27 of which can be accessed free at:

http://genesdev.cshlp.org/content/8/8/981.full.html\#ref-list-1

License

Email Alerting

Service

Receive free email alerts when new articles cite this article - sign up in the box at the top right corner of the article or click here.

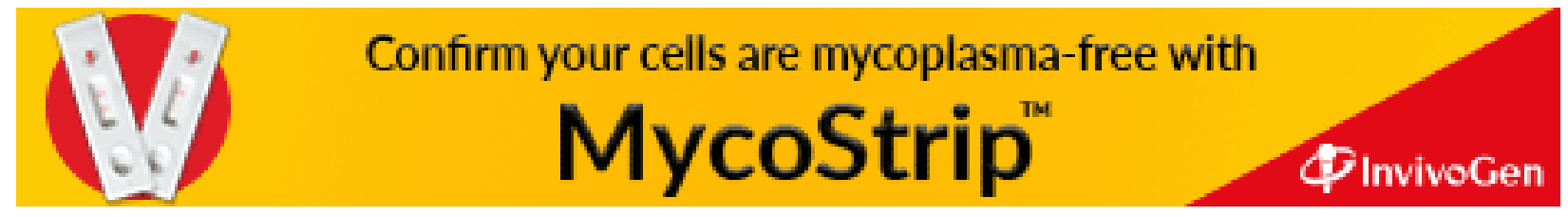

